\title{
Reproductive indicators of first-calf heifers when using a complex mineral-vitamin feed additive
}

\author{
M.T. Sabitov*, A.R. Farkhutdinova, M.G. Malikova, and A.L. Aminova \\ Ufa Federal Research Center of the Russian Academy of Sciences, Bashkir Research Institute of \\ Agriculture, Ufa, Russia
}

\begin{abstract}
A method for improving the reproductive performance of firstcalf heifers using a complex mineraland vitamin feed additive is presented to the production. The animals of the control group were fed according to the main diet accepted in the farm and mineral matters. The animals from group I were fed the main ration with $120 \mathrm{~g}$ of the complex mineraland vitamin feed additiv per head according to recipe No.1. The animals from group II received the main ration with $120 \mathrm{~g}$ of the feed additive per head according to recipe No.2. The cow mating index of the first heifers of the control group is 2.1 , which is 0.48 and 0.60 times higher than in groups I and II. The highest rate of fecundation showed the cows of the experimental group II. It made up $63 \%, 7 \%$ higher than the experimental group I $(56 \%)$ and $18 \%$ higher than the control group (45\%). After the second fecundation, the conception rate in group II was $37 \%$, which is $18 \%$ higher than in the control group and $7 \%$ higher than in animalsof group I. The calf crop in all groups was $100 \%$.
\end{abstract}

\section{Introduction}

The lack of minerals and vitamins in the diet leads to metabolic disorders, decreased immunity, milk productivity and reproductive ability of cows [1]. Scientists indicate in their studies that the lack of copper, manganese, cobalt leads to anaemia development and lousy absorption of calcium and phosphorus in the gastrointestinal tract. Moreover, zinc exchange is associated with calcium exchange, and the lack of iodine leads to a decrease in oxidative processes and nitrogen metabolism [2]. Therefore, the diets of lactation cows need careful monitoring for the content of macro and micro-elementssince they play an essential role in metabolism, are part of enzymes, hormones and vitamins and other biocatalysts [3-4].

Trace elements are biocatalystsand have a direct influence on both productivity and health, and animal reproduction. Zinc activates the pituitary gland and affects such sex hormones as follicle-stimulating (FSH) and luteotropic (prolactin). Selenium and vitamin E deficiency can cause cows infertility due to early embryonic demise, delayed or incomplete separation of the placenta. When diets are poor in manganese, there is a puberty delay in

*Corresponding author: sci_secr_bniish@bk.ru 
young animals and irregular ovulation in adult cows [5]. The lack of copper in the diets of pregnant cows leads to the development of congenital anoxia and hypotaxia in calves [6-8].

The Bashkir Research Institute of Agriculture of the Russian Academy of Sciences developed a CMVFA recipe forfirst-heifers considering the standards recommended by A. P. Kalashnikov (2003), the actual content of mineral elements in feed and their deficiency in diets. The feed additive contains substances important for cows. They are natural zeolith of the Tuzbek deposit of the Republic of Bashkortostan, premix P-60-1-1\% (GOST 523562005) containing salts of macro-and micro-elements, and vitamins A, D and E, feed sulfur meeting the requirements of CS (Company Standard) 46484954-0021-2011, magnesite meeting the requirements of GOST 32343-2013; defluorinated phosphate(DFF, $\mathrm{Ca}_{4} \mathrm{Na}$ $\left.\left(\mathrm{PO}_{4}\right)_{3}\right)$ of line $\mathrm{P}$ meeting the requirements of industrial standard 2182-001-503371092006; natural feed chalk meeting the requirements of GOST 17498-72; table salt (table 1).

Table 1. CMVFA recipes for first-calf heifers.

\begin{tabular}{|l|c|c|}
\hline \multirow{2}{*}{ Composition } & \multicolumn{2}{c|}{ Recipes } \\
\cline { 2 - 3 } 1 kg of CMVFA containsvitamins: \\
\hline \multirow{2}{*}{ Ah, Thd. MU } & 300 & 250 \\
\hline D, Thd. MU & 120 & 100 \\
\hline E, mg & 280 & 235 \\
\hline \multicolumn{2}{|c|}{$1,74: 1$} & $1,68: 1$ \\
\hline The ratio of Ca:P & 192 & 170 \\
\hline Phosphorus, & 333 & 285 \\
\hline Calcium & 104.5 & 100 \\
\hline Sulfur, & 70.8 & 85 \\
\hline Magnesium & 50 & 60 \\
\hline Sodium from table salt & 250 & 300 \\
\hline Zeolith, up to 1000 g & 3,890 & 3,520 \\
\hline \multicolumn{2}{|c|}{ Micro-elements, mg: } \\
\hline Zinc & 1,200 & 985 \\
\hline Manganese & 260 & 235 \\
\hline Copper & 40 & 30 \\
\hline Cobalt & 40 & 30 \\
\hline Iodine & 20 & 20 \\
\hline Selenium & 100 & 100 \\
\hline $\begin{array}{l}\text { The daily input rate per } \\
\text { 1 head }\end{array}$ & \multicolumn{2}{|c|}{} \\
\hline
\end{tabular}

The research aims to study the heifers' reproductive indicators when receiving mineral supplements as part of their diet (premix P-60-1-1\%, feed chalk, table salt) and the CMVFA developed by the Bashkir Research Institute of the Russian Academy of Sciences and made according to recipes No.1, No.2. The research gives a justification for their use.

\section{Materials and methods}

The scientific and economic experience was carried out on the Valiev stud farm of the Diurtiulinsky district of the Republic of Bashkortostan. Healthy heifers of the Black-andWhite breed, selected by the analogue method, were used for the experiments. There were 3 experimental groups with 25 cows in each. The pregnancy period of all the caws was the same (7 months. Their live weight was on average $480.0 \mathrm{~kg}$. All the cows belonged to lineV.B. Ideal 1013415). The experiment lasted for 2 months. 
The animals of the control group received the main diet (MD) adopted on the farm and minerals. Group I received the main diet and the CMVFA according to recipe No. 1. Group II received the main diet and the CMVCD according to recipe No. 2.

The daily norm of the CMVFA in the experimental groups was $100 \mathrm{~g} / \mathrm{head}$. It was determined by the daily requirement, depending on cows' productivity and the deficiency of these substances in the diet. The CMVFA was fed with a crushed grain mixture (wheat, barley, oats, rye) following the recipes for each group.

The conditions of keeping all the experimental cows were the same.

The diets of experimental cows changed three times a month depending on the feed consumptionand the planned milk productivity of the cows.

The diet of the experimentalcowsconsisted of hay and haylage of cerealsand legumes, perennial grasses of medium quality, grain and legume silage from annual grassesof class II. Concentrated feed $(1.5 \mathrm{~kg})$ was used as part of a feed mixture, $2 \mathrm{~kg}$ - of which was in dry formsince the daily norm of the CMVFA was introduced into the composition of concentrates, and the other part ( $2.5-3 \mathrm{~kg}$. and $1.5 \mathrm{~kg}$ of molasses) was given in a malted form during the morning feeding depending on productivity.

\section{Results and discussion}

During themilking period, the first-calf heifers need a balanced nutritious diet containing sufficient energy, nutrients, and mineral elements and vitamins that activate many enzymes and hormones, determining the metabolism intensity [4,9].

Consideringthe introduction of individual mineralsubstances, for animals of the control group, per 1 forage unit, there were $7.12 \mathrm{~g}$ of calcium, $3.02 \mathrm{~g}$ of phosphorus, $1.85 \mathrm{~g}$ of magnesium, $1.72 \mathrm{~g}$ of sulfurg. As for trace elements, there was $7.33 \mathrm{mg}$ of copper, 62.14 $\mathrm{mg}$ of zinc; $59.61 \mathrm{mg}$ of manganese; $0.24 \mathrm{mg}$ of cobalt and $39.98 \mathrm{mg}$ of carotene. The animals of the experimental group I received the CMVFA. Thus, they received the following mineral substances:8.90 mg of calcium; $3.34 \mathrm{mg}$ of phosphorus; $2.29 \mathrm{mg}$ of magnesium; $1.99 \mathrm{mg}$ of sulfur. They also received micro-elements such as $7.82 \mathrm{mg}$ of copper, $89.66 \mathrm{mg}$ of zinc, $70.2 \mathrm{mg}$ of manganese, $1.02 \mathrm{mg}$ of cobalt and $32.98 \mathrm{mg}$ of carotene. In group II, the animals received $8.74 \mathrm{~g}$ of calcium, $4.50 \mathrm{~g}$ of phosphorus, $2.73 \mathrm{~g}$ of magnesiumand $2.94 \mathrm{~g}$ of sulfur. They also received micro-elements: $11.22 \mathrm{mg}$ of copper, $86.36 \mathrm{mg}$ of zinc, $69.39 \mathrm{mg}$ of manganese, $1.0 \mathrm{mg}$ of cobalt, and $31.25 \mathrm{mg}$ of carotene.

After balancing, the analysis of the diets showedthat the content of nutrients and minerals correspond to the normative indicators of A. P. Kalashnikov et al. (2003) and provide their total need.

$1 \mathrm{~kg}$ of dry matter of the first-calf heifers' diet of the control group contains 204.87 MU of vitamin D and $25.85 \mathrm{mg}$ of vitaminE. In group 1, the diet contains 263.6 ME of vitamin $\mathrm{D}$ and $29.8 \mathrm{mg}$ of vitamin E. In group II, the content of vitamin D is 27.94MU, and vitamin E makes $30.34 \mathrm{mg}$.

The deficiencyof macro and micro-elements and vitamins in first-calf heifers' diets is balanced by the CMVFA, which contains natural zeolith, macro and micro-elements, and vitamins.

An indicator of the reproductive ability of cows is the fecundation index, i.e., the number of fecundations per pregnancy. In animal husbandry, the fecundation index equal to 1.5 is considered excellent, 2.0-2.5-satisfactory. An increased fecundation index indicates a problem in the reproduction of the herd. 
According to several researchers, the optimal period for milk production [10] should be considered a dry period lasting 50-60 days [11-13]. The reproductive qualities of experimental cows are shown in Figure 1.

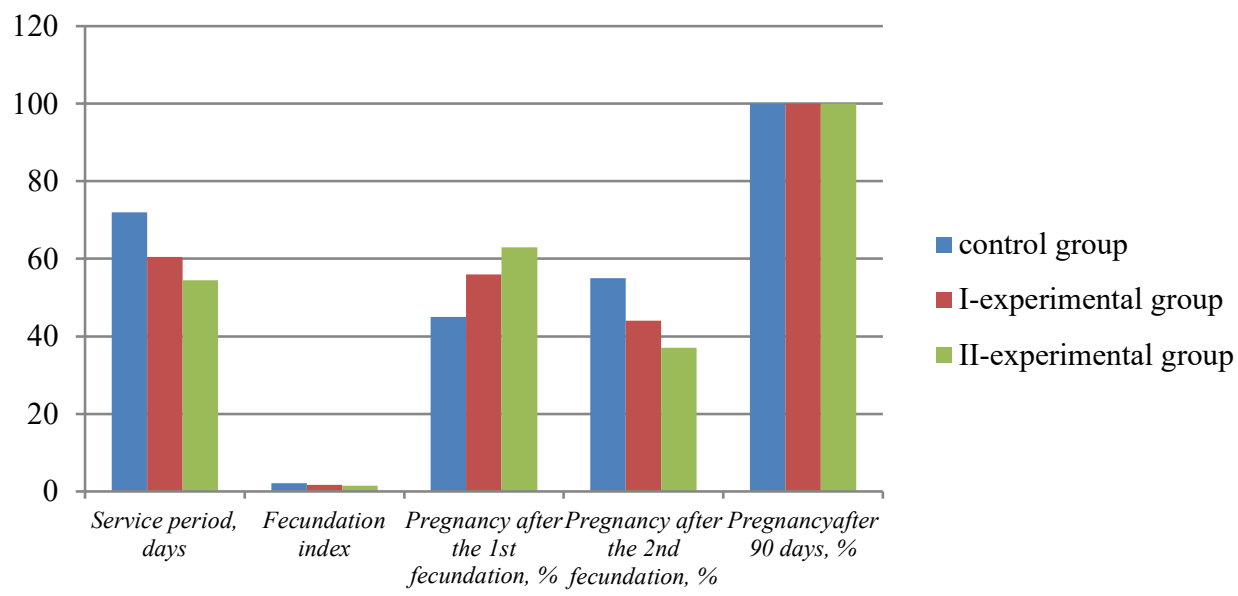

Fig. 1. Reproductive qualities of cows.

The service period of the cows of the control group was 72 days, of group I - 60.5 and group II - 54.5 days. Therefore, the service periodof the experimental groups was 11.5-17.5 days shorter. Besides, the fecundation index is $0.48-0.60$ times lower than in the control group. After the first fecundation, $45 \%$ of cows of the control group were fertilized. The fecundation index in the experimental groups was $56 \%$ and $63 \%$, respectively,i.e. 11 and $18 \%$ higher than in the control group. After the second fecundation, the conception rate in group II was $37 \%$, which is $18 \%$ higher than in the control group and $7 \%$ higher than in animalsof group I. The cow pregnancy in all groups was confirmed90 days after the second fecundation. Thus, the analysis of the reproductive ability of experimental animals showed that the cows of the control group had a lower fecundation index. Thus, the first-calf heifers of the control group had a low fecundating ability since 2.1 sperm doses were spent on their productive fecundation. As for the experimental cows, 1.62 and 1.50 sperm doses were spent on their fecundation, respectively. Thus, the indicators prove the optimization of the sexual cycle in animals of the experimental groups I and II when feeding them with the CMVFA.

The calf crop in all groups was $100 \%$. The live weight of calvesborn to experimental cowsof group I averaged $32.5 \mathrm{~kg}$ which is $1.3 \mathrm{~kg}$ more. Ingroup II, it was $34.8 \mathrm{~kg}$, whichis $3.6 \mathrm{~kg}$ morethan calves born to the cows of the control group $(31.2 \mathrm{~kg})$. During the mother-bonded calf rearing, the calves livability was $98.2 \%$ in the control group and $100 \%$ in the experimental groups.

\section{Conclusion}

Thus, the reproductive indicators provethat the CMVFA, used in the diets of heifers in the last stage of pregnancy (7-9 months.), contributes to better development of calves during ontogenesisand after their birthand helps them to get ready for lactation. The feed additive provides the calves with required nutrients, making it possible to improve reproductive performance by reducing the calving and service periods and the fecundation index. 


\section{References}

1. V.V. Akhmetova, N.A. Lubin, Bulletin of the Ulyanovsk State Agricultural Academy 1 (29), 41-44 (2015) (In Russ.)

2. T.S. Kuznetsova, S.G. Kuznetsov, A.S. Kuznetsov, Zootechniya, 8, 10-14 (2007) (In Russ.)

3. S.M. Krivich, L.P. Yarmots, A.Sh. Khamidullina, G.A. Yarmots, Chief zootechnic 1, 17-19 (2013) (In Russ.)

4. G.A. Yarmots, Agro-food policy of Russia, 2 (26), 61-63 (2014) (In Russ.)

5. V.V. Tashlanov, M.V. Varenikov, M.N. Butkeev, B.V. Levchenko, Dairy and meat cattle breeding, 4, 32-35 (2016) (In Russ.)

6. I.Yu. Kuzmina, E.V. Ginter, A.M. Kuzmin, Dairy and meat cattle breeding 3, 31-38 (2020) (In Russ.)

7. B.D. Kalnitsky, S.G. Kuznetsov, O.V. Kharitonova, Zootechniya 9, 29-33 (1991) (In Russ.)

8. L.F. Androsova, Zootechniya 9, 16-18 (2004) (In Russ.)

9. M.A. Nadarinskaya, Animal science 12, 10-11 (2004) (In Russ.)

10. U. Breme, New agriculture 5, 116-118 (2007) (In Russ.)

11. P. Moller, Present experimental result on protein-energy releti onships in dairy and beef cattle feeding in Denmark, 165-190 (Geneva, Pergamon Press, 1982)

12. N. Sir, Dairy and beef cattle 8, 11-13 (2007) (In Russ.)

13. V.A. Bekeneva, Agricultural biology, 54 (4), 655-666 (2019) (In Russ.) 